\title{
जic
}

Stem cell



\section{Bone tissue engineering with human stem cells}

Marolt et al.

C Biomed Central 


\section{Bone tissue engineering with human stem cells}

Darja Marolt' ${ }^{1}$ Miomir Knezevic ${ }^{2}$ and Gordana Vunjak Novakovic*1

\begin{abstract}
Treatment of extensive bone defects requires autologous bone grafting or implantation of bone substitute materials. An attractive alternative has been to engineer fully viable, biological bone grafts in vitro by culturing osteogenic cells within three-dimensional scaffolds, under conditions supporting bone formation. Such grafts could be used for implantation, but also as physiologically relevant models in basic and translational studies of bone development, disease and drug discovery. A source of human cells that can be derived in large numbers from a small initial harvest and predictably differentiated into bone forming cells is critically important for engineering human bone grafts. We discuss the characteristics and limitations of various types of human embryonic and adult stem cells, and their utility for bone tissue engineering.
\end{abstract}

\section{Clinical need for bone grafting}

Bones are organs of the skeletal system, providing shape, mechanical support and protection to the body, and facilitating movement. In addition, bones contribute to the mineral homeostasis of the body and have recently been found to participate in endocrine regulation of energy metabolism [1]. During development, bones form by two distinct processes [2]: intramembraneous and endochondral ossification. In intramembanous ossification, cells of the condensed mesenchymal tissue differentiate into osteoblasts and directly form bone. In contrast, endochondral ossification involves the formation of cartilaginous anlage, which then undergoes calcification and invasion by blood vessels, resulting in the formation of new bone by mesenchymal stem cells [3].

Adult bones are supplied by blood and constantly undergo remodeling, which allows adaptation to mechanical stresses, maintenance of bone health, and repair of small injuries. A recent study demonstrated very

*Correspondence: gv2131@columbia.edu

'Department of Biomedical Engineering, Columbia University, 622 West 168th

Street, New York, NY 10032, USA

Full list of author information is available at the end of the article elegantly that the coupling between osteoclastic bone resorption and osteoblastic bone formation is needed to maintain bone health, and that both processes are mediated by tumor growth factor- $\beta$ [4]. Similarly, coordinated responses of bone tissue, bone marrow, periosteum and surrounding soft tissues are needed for bone repair, which involves elements of both endochondral and intramembranous ossification [5]. A tight control of the balance between bone formation and resorption determines normal turnover of bone tissue throughout the lifetime.

Frequently, clinical situations arise where extensive injury, congenital malformations or diseases cause large bone defects, and reconstruction with tissue grafting is needed. Autologous grafts contain the essential components of bone regeneration - osteogenic cells, osteoinductive growth factors and bone-supporting matrix but are not readily available in every situation. Other limitations include morbidity at the donor site (which often heals more slowly than the repair site) and difficulties in preparing anatomically shaped grafts from the harvested bone. Alternatives, including allogeneic bone transplantation, have their own limitations, such as tissue matching, disease transmission, batch variability, and an inability to survive and integrate following implantation [6]. Additionally, the large variability in bone defects, the huge complexity of bone architecture, and the high metabolic activity of bone, necessitating immediate blood supply, motivate the development of new treatment strategies [7].

\section{Engineering viable human bone in vitro}

Current models of bone formation in vitro are based on the paradigm that cellular differentiation and function can be modulated by the same factors known to play a role during embryonic development [8]. In order to engineer an environment supporting bone formation, combinations of biochemical and biophysical signals need to be presented to the cells in a three-dimensional setting in a way that allows cellular interactions with the surrounding cells and extracellular matrix (Figure 1, left). The complexity of signaling - with temporal and spatial gradients of molecular and physical factors affecting bone morphogenesis - presents significant challenges to engineering fully viable, functional bone. 


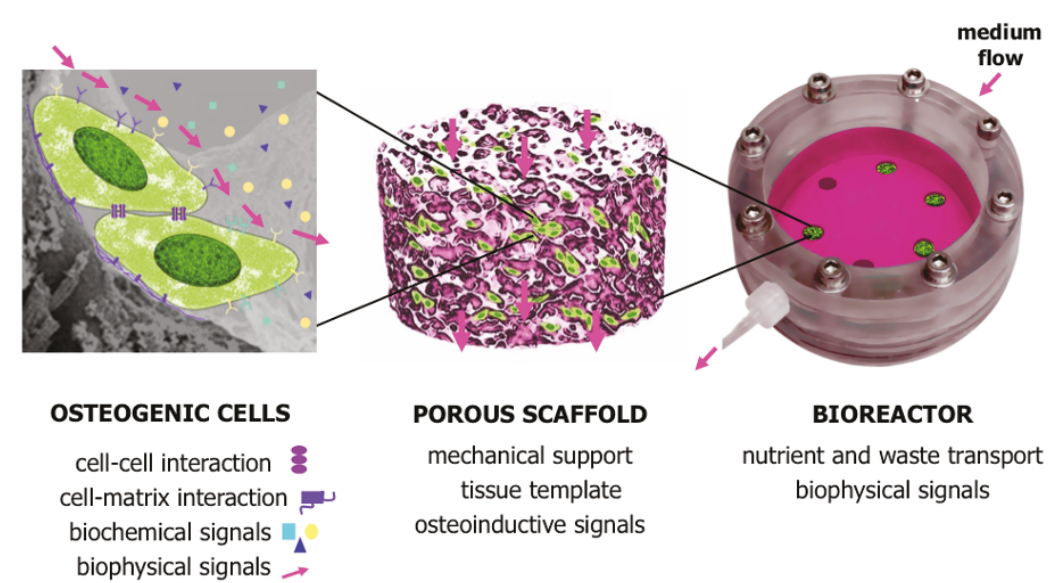

Figure 1. Schematic representation of bone formation in vitro. Left: cells are growing attached to the scaffold surface, and sense microenvironmental signals. Middle: porous scaffolds offer support and a template for new tissue formation. Cell viability is maintained by medium perfusion through the scaffold interior. Right: dynamic culture in bioreactors enables control of medium flow and environmental parameters supporting in vitro osteogenesis.

One key component of the in vitro bone model is the scaffold, which provides a structural and logistic template for the developing tissue, and can markedly affect cell behavior (Figure 1, middle). Several types of porous scaffolds have been shown to support in vitro bone formation by human cells, including those made of ceramics $[9,10]$, native and synthetic polymers $[11,12]$ and composite materials [13].

Scaffold properties important for bone formation include: the size, distribution and shape of the pores [14]; surface roughness [15]; the presence of cell attachment sites [16]; and the biomechanics of both the material [17] and the scaffold structure. In general, the most suitable scaffolds for bone formation are those with large and interconnected pores (which facilitate cell infiltration and matrix deposition) and rough inner surfaces (which facilitate cell attachment), made of osteoconductive materials (such as bone protein and hydroxyapatite), and with mechanical properties similar to those of native bone (both to enable load-bearing and stimulate osteogenesis). Additional features of interest include anisotropic structure, capacity for vascularization, and processability into anatomically correct shapes. Scaffolds can also incorporate and modulate delivery of molecular signals controlling cellular functions [18].

Another key component of bone tissue engineering is the culture system or bioreactor. Bioreactor systems can be designed to control transport of nutrients and oxygen to cells in clinically sized constructs and provide lineagespecific biological stimuli in various regions of the graft [19]. Additionally, the development of functional, loadbearing characteristics of the graft would be enhanced by the application of biophysical stimulation in order to attain mechanical competence in both the cartilage and bone regions.

Advanced bioreactor designs maintain the physiological milieu in the cell microenvironment $(\mathrm{pH}$, temperature, oxygen and nutrient delivery) by perfusion and conditioning of culture medium (Figure 1, right). Bioreactors can also be designed to recapitulate one or more of the developmentally relevant biophysical signals in a time-controlled manner. For example, increased mass transport and fluid shear by medium perfusion [20-22], and cyclic loading [23] have been shown to improve osteogenesis and enable formation of homogenous bone constructs. Ideally, a bioreactor system should be capable of coordinating biological, physiological and mechanical stimuli, and applying them in a spatially and temporally controlled manner to provide lineage-specific stimulation within clinically sized grafts.

The clinical and scientific utility of tissue engineering largely depends on our ability to predictably direct cells to differentiate into the right phenotypes in a spatially and temporally defined pattern. The control of environmental conditions provided through the design of bioreactors - in conjunction with scaffolds - can help gain more insight into the interplay of molecular and physical factors that guide the development of bone from various types of osteogenic cells. Understanding of the developmental process may then serve as feedback to the optimization of engineering parameters toward better graft designs, and towards the use of engineered grafts as models of development and disease.

\section{Sources of human osteogenic cells}

There are several basic considerations when choosing a cell source for bone tissue engineering: the choice 
between the patient's own (autologous) cells or the use of another person's (allogeneic) cells; the availability and ease of tissue harvesting with minimal donor site morbidity; the efficiency of cell isolation and cell yield; the use of primary osteogenic cells with limited potential for proliferation, or self-renewing stem cells; the use of cells that have both osteogenic and vasculogenic potential, to support the formation of vascularized bone; the homogeneity of the obtained cell population and controllable induction of the osteogenic phenotype; phenotype stability and cell safety after implantation; and the possibility of automation and the development of quality control measures for the generation of cells and grafts.

In most cases, cells are isolated from a tissue harvest and expanded in vitro prior to bone construct preparation. An expansion step increases the number of osteogenic cells (approximately $70 \times 10^{6}$ osteoblasts are needed to form $1 \mathrm{~cm}^{3}$ of new bone) [24], but could also be used for selection and enrichment of the appropriate cell population(s). Cells with high biosynthetic activity are desirable for enhanced bone formation in vitro and subsequent integration with the host tissue. Stable expression of the osteogenic phenotype could aid bone regeneration, and is critical in order to avoid non-specific tissue development. Several clinical reports of cell-based tissue engineering approaches for bone regeneration are summarized in Table 1.

\section{Cells from bone tissue and periosteum}

Adult bone tissue and periosteum can be used as sources of primary osteogenic cells [25-28]. Isolation techniques usually involve preparation of explant cultures from the dissected tissues, or enzymatic release of progenitor cells from the endosteal and periosteal layers (Figure 2a). Stepwise collagenase digestion has been used for the preparation of osteoblast-like populations with lower proportions of adherent stromal cells [25,29]. In some studies, fetal bone tissue has been used as a potential alogeneic source due to fast cell proliferation and has demonstrated osteogenic potential [30].

In vitro, between 20 and 40 population doublings have been reported for primary bone and periostal cells $[31,32]$. Studies have indicated differences in proliferation rates of the bone cells isolated by different methods and originating from different donors, as well as age-related declines in cell proliferation $[26,27,30]$. Differences in the proliferation potentials of bone cells isolated from different sites have been observed [29,33], similar to bone marrow stromal cells originating from different sites [34].

In most studies, the expression of osteogenic markers (for example, increased alkaline phosphatase activity, synthesis of osteopontin, bone sialoprotein, osteocalcin and extracellular matix calcification) has been noted in the presence of the osteogenic supplements 1,25-dihydroxy vitamin D3, dexamethasone, $\beta$-glycerophosphate and L-ascorbic acid [35,36], but only a limited amount of work has directly compared the functional potentials of osteogenic cells isolated from different sources [37]. In addition to osteogenesis, it has been reported that periosteal and endosteal populations also exhibit chondrogenic and adipogenic differentiation potential $[31,32]$.

Primary human bone and periosteal cells cultured on porous scaffolds formed bone-like tissue [11,38,39]. In separate studies, bone constructs have been engineered from periosteal cells and used clinically to enhance healing of periodontal defects (Table 1).

Taken together, these studies demonstrate that primary osteogenic cells can be isolated from tissues discarded during surgical procedures and used for in vitro studies [33], and suggest that harvests of small tissue volumes from relatively accessible sites (for example, jaw bones during dental implant placement) could potentially be used for cell isolation and preparation of autologous grafts up to several millimeters in diameter and length. In contrast, due to donor site morbidity [40-42] and limited proliferation of primary cells, it would be difficult to envision routine preparation of large autologous grafts (several centimeters in diameter and length) from primary bone or periosteum-derived cells (Table 1). The applicability of such approaches will strongly depend on developing robust cell preparation procedures from source tissues that are inherently variable due to donor age, gender, health status, systemic conditions and genetic background.

\section{Adult stem cells}

Adult mesenchymal stem cells capable of differentiation into bone, cartilage, adipose, muscle, tendon, ligament and marrow stroma have been found in a variety of tissues, including bone marrow, adipose tissue, synovium, dental pulp, cord blood, umbilical cord and others [43-46]. For bone regeneration, the most studied source has been the bone marrow, as it was recognized early that its stroma contains bone marrow mesenchymal stem cells (BMSCs) capable of forming bone and cartilage [47]. Bone marrow transplantation is also being used clinically in combination with osteoconductive materials to augment bone healing $[6,48]$.

BMSCs are commonly isolated based on their adherence and growth on tissue culture plastics (Figure 2b). Alternatively, pure bone marrow aspirates can be used to immunoselect BMSCs using specific surface markers. The small initial numbers of immunoselected cells are then expanded in culture to obtain sufficient cell mass for therapeutic purposes. The number of stem cells ( 0.001 to $0.01 \%$ of the nucleated marrow cells) [43] varies between 
Table 1. Overview of clinical studies in which tissue engineered grafts were applied for bone regeneration

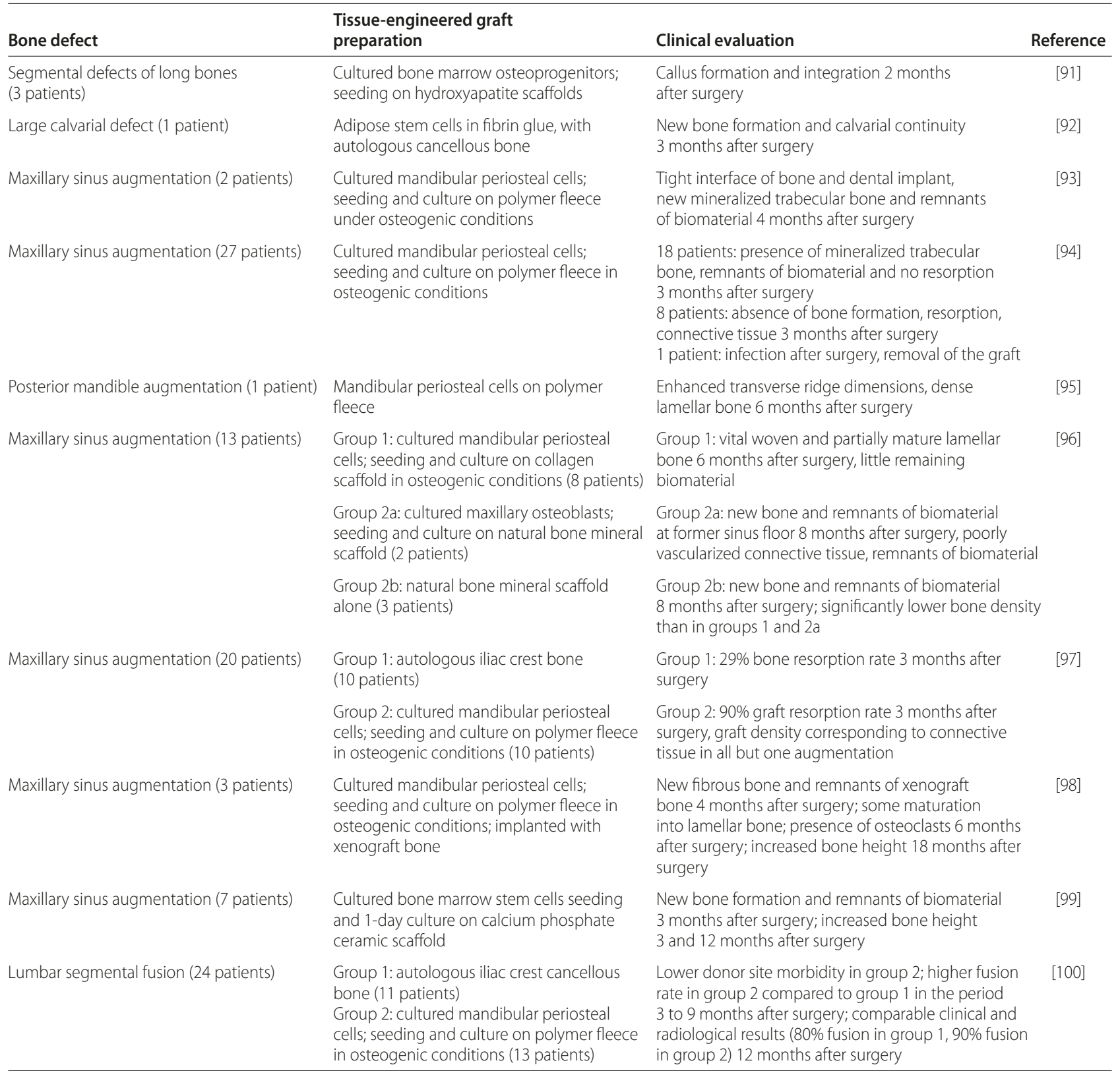

different patients and reportedly declines with patient age [46]. Additionally, marrow aspiration volume (up to $150 \mathrm{ml}$ ) and technique can influence the number of isolated stem cells [48]. BMSCs can, however, be cultureexpanded to large numbers and have been reported to reach up to 50 population doublings in vitro [49]. Importantly, studies suggest that the osteogenic potential of BMSCs is maintained in older individuals [46], and appropriate conditions in vitro (for example, culture on collagen substrate, growth factor supplementation of culture media) $[50,51]$ can help maintain cell differentiation potential.
Adipose tissue stem cells (ASCs), discovered more recently [44], represent another attractive source for bone tissue engineering due to their accessibility and potential for differentiation into osteogenic, chondrogenic, adipogenic and endothelial lineages [52]. Lipoaspirate volumes can range from $100 \mathrm{ml}$ to several liters and contain a relatively high frequency of ASCs (1 to 5\% of isolated nucleated cells) [53]. Cell isolation protocols usually include density gradient centrifugation of the collagenase-digested tissue (lipoaspirate or minced adipose tissue) and culture of the adherent cell population (Figure 2c). Similar to BMSCs, the numbers of 

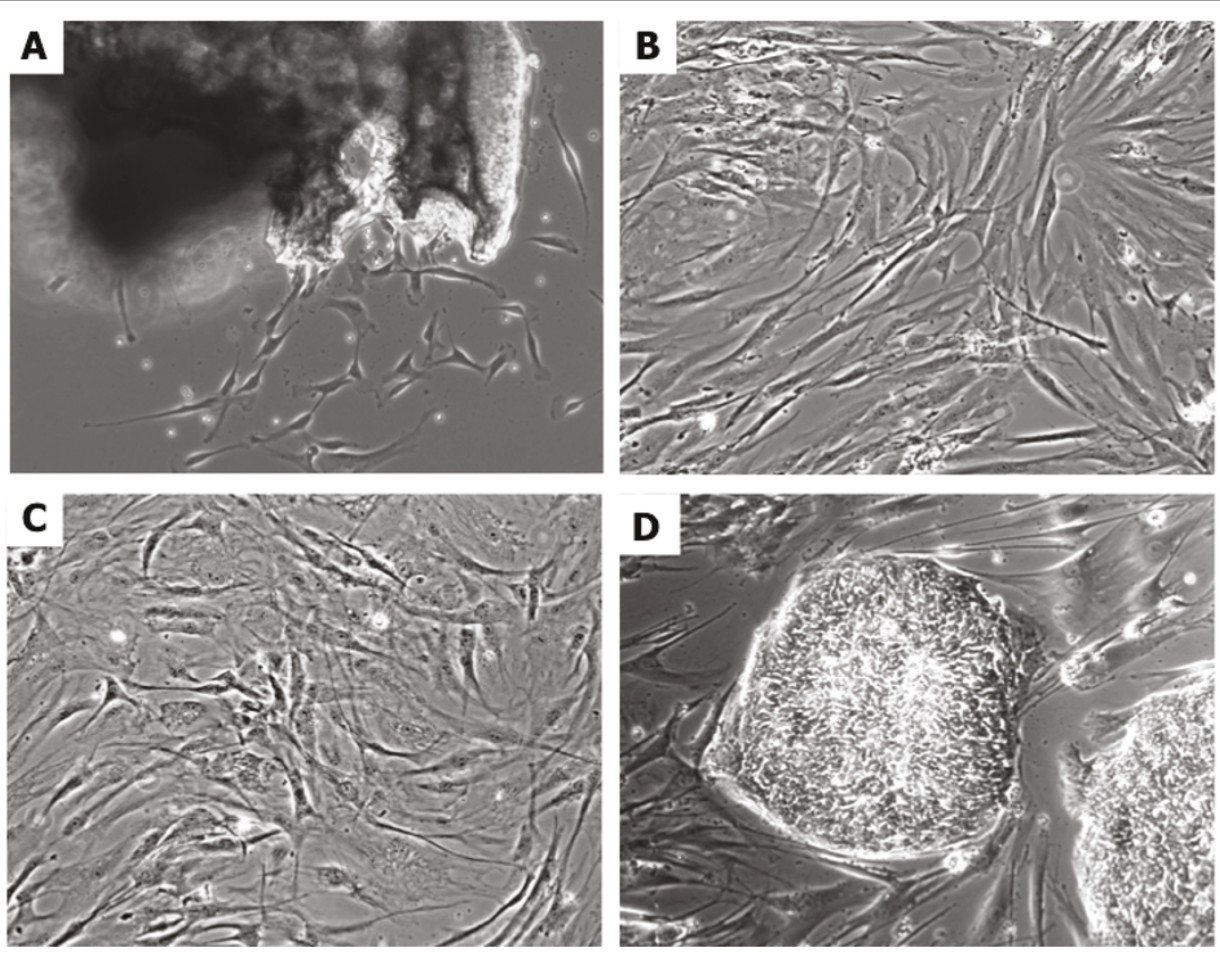

Figure 2: Examples of human osteogenic cells growing in vitro. (A) Primary explant culture of bone cells. (B) Bone marrow mesenchymal stem cells. (C) Adipose stem cells. (D) Human embryonic stem cells (line H13) growing on mouse embryonic fibroblasts. Original magnification: 100x.

isolated stem cells are influenced by the tissue harvesting procedure, as well as the site of tissue harvesting (for example, arm, thigh, abdomen, breast) [52].

Several groups have reported the formation of bonelike constructs from BMSCs and ASCs cultured on porous scaffolds [54-56], and noted positive effects of dynamic bioreactor culture on cell distribution and matrix formation $[12,20,21]$. Recently, our group has reported engineering of fully viable, clinically sized, and precisely shaped temporomandibular joint grafts by culturing BMSCs on anatomically shaped scaffolds in specially designed 'anatomical' bioreactors [57]. This study illustrates the feasibility of using adult stem cells for engineering functional human bone grafts, and underlines the importance of perfusion culture to support physiologic cell densities, as well as formation of dense, homogenously distributed bone matrix.

Survival of large engineered grafts after implantation remains an open question due to the need for immediate connection to the host vasculature, which is an unsolved problem of all tissue engineering. Various strategies for pre-vascularization are currently under investigation [7]. For example, Scherberich and colleagues [58] obtained bone constructs with intrinsic vascularization potential by culturing isolated adipose stromal vascular fractions on porous scaffolds in perfusion for 5 days. These efforts could enhance the survival of implanted grafts once the methods become available for the connection of the graft to the blood supply of the host.

A few clinical studies have reported on bone constructs prepared from adult stem cells and implanted to enhance bone regeneration. Importantly, adverse side effects of the transplanted cells have not been reported, and the authors suggested possible positive effects of transplanted cells on bone regeneration (Table 1).

\section{Differentiation potential and phenotype stability of adult stem cells}

Differentiation potentials of adult stem cells obtained from various sources are under investigation, as are the culture conditions required to achieve the functional properties of terminally differentiated cells. Another focus is determining correlations between the phenotypes of cultured cells and their potential for functional differentiation. Stem cells isolated from various tissues are frequently evaluated for the expression of surface antigens by flow cytometry [43,45], and share common patterns between various BMSC preparations, and a highly conserved profile between ASC preparations [52]. In spite of the relative uniformity of marker expression, the cell potential to deposit bone matrix can vary quite significantly between different donors and cell populations $[21,59]$. 
Simple models for evaluating the differentiation potential of cells are provided by micromass and pellet cultures. Pellets are prepared by centrifugation of several hundred thousand cells, and incubated in differentiation media for specific differentiation paths - in most cases osteogenic, chondrogenic and adipogenic. Micromass cultures are prepared by plating droplets of high cell density suspensions on tissue culture plates, which are also incubated in specific cell differentiation media. In both systems, high cell density helps mimic cell interactions and cell condensation events present during native development of cartilage and bone.

Osteogenesis and chondrogenesis can be measured quantitatively using molecular, biochemical and histological assays [12,21]. Bone formation capacity can also be evaluated in vivo - for example, in ectopic bone formation models [60]. In a recent study, correlations between bone marker gene expression and functional osteogenesis assays have been made to construct a mathematical model for predicting the bone forming capacity of the synovial and periosteal stem cells [60]. In future, such models could possibly be implemented in culture protocols to help develop robust procedures for manufacturing bone grafts.

Several reports of long-term BMSC and ASC cultures ( $\geq 4$ months, $\geq 30$ doublings) have indicated changes in cell cycle kinetics and the possibility of abnormal karyotype development, leading to malignant cell transformation [61,62]. These studies identified some limitations of ex vivo manipulation, which should be taken into consideration and explored further to ensure the biosafety of adult stem cells before their clinical application.

\section{Embryonic stem cells and induced pluripotent stem cells}

Pluripotent human embryonic stem cells (ESCs) can form any tissue of the body and have exhibited an unsurpassed (possibly unlimited) potential for proliferation in vitro [63]. ESCs were first successfully isolated and cultured in 1998 by Thomson and colleagues [64], and have enormous value as a potential source of cells for regenerative medicine, as well as a model of early human development. In bone tissue engineering, ESCs could be used as a single source for the derivation of multiple lineages present in adult bone, including osteogenic cells, vascular cells, osteoclasts, nerve cells and others.

Compared to adult stem cells, ESCs require complex culture conditions: they are commonly derived from blastocyst-stage embryos and cultured on mitotically inactivated murine feeder cells in media supplemented with basic fibroblast growth factor and other factors [63]. ESCs grow in colonies, and are passaged as small aggregates by mechanical or enzymatic dissociation from the feeder cells. In recent years, progress has been made, and completely defined feeder-free conditions have been reported [65]. In an alternative approach, human feeder cells (for example, skin fibroblasts) have been used for ESC culture [66].

Similar to adult stem cells, pluripotent ESCs are characterized by the expression of specific surface antigens, including stage-specific embryonic antigen-4 (SSEA-4), tumor rejection antigens TRA-1-60 and TRA-1-81, and the absence of SSEA-1 [67]. Other markers associated with undifferentiated ESCs are high alkaline phosphatase and telomerase activities, and expression of transcription factors Oct4, Sox2 and Nanog, which are crucial for the maintenance of pluripotency [68]. A standard test for confirming human ESC differentiation potential in vivo is the formation of teratomas after cell injection in immunodeficient mice. Pluripotency can also be evaluated in vitro by inducing differentiation in embryoid bodies (aggregates of cells cultured in suspension) and observing formation of tissues from all three germ layers [67].

Spontaneous development of abnormal karyotypes and other genetic alterations have been observed during prolonged cultivation of ESCs $[69,70]$. Therefore, frequent monitoring of the karyotype is recommended, and further studies are needed to ensure stability and safety of the ESC-derived progenitor populations before their potential use in regenerative medicine.

Recently, the prospect of using ESCs for autologous therapies has gained attention with reports of induced pluripotent stem cells derived from adult differentiated cells [71]. Induced pluripotent stem cells share many characteristics with ESCs, including morphology, proliferation, surface antigens, gene expression, epigenetic status and pluripotency. Development of safer alternatives for cell reprogramming (for example, excluding genetic manipulation) could potentially provide a cell source for autologous therapy [72]. Currently, however, these cells present a unique opportunity to study the development and progression of genetic diseases in vitro.

\section{Osteogenesis of embryonic human stem cells}

The pluripotent nature of ESCs presents a challenge to the development of efficient protocols for directing cells into specific lineages. The embryoid body step has been an integral part of many differentiation protocols, including osteogenic differentiation. Cells capable of osteogenesis have been found in mixed populations of progenitor cells present in embryoid bodies after 4 to 5 days of culture $[73,74]$, and populations arising from co-cultures with primary bone and periodontal ligament cells $[75,76]$. A direct differentiation protocol excluding the embroid body step has also been tested, and seemed to enhance ESC osteogenesis in vitro [77]. 
Alternatively, induction and isolation of mesenchymal stem cells (MSCs) from ESCs has been attempted, and these MSC-like progenitors have been subsequently directed into the osteogenic lineage (mostly in monolayer culture). In one study, MSC-like progenitors have been obtained by mechanical isolation of spontaneously differentiated cells from ESC cultures, followed by longer culture in confluent monolayers [78]. In another study, co-culture with stromal cells was used to induce differentiation, followed by immunoselection of a MSC-like population [79]. More recently, exposure of ESCs to serum and growth factor supplemented media $[80,81]$ has been used to induce differentiation, and MSC-like progenitors have been expanded in a subsequent monolayer culture. Whereas these studies elucidate some of the factors involved in osteogenesis of ESCs, further work is needed to gain a better understanding of the developmental processes involved in specification to bone-forming cells, as well as to evaluate the stability and functionality of the obtained populations [82].

\section{Genetically engineered osteogenic cells}

In vivo implantation of stem cells genetically engineered to carry osteogenic genes has been shown to induce rapid bone formation, indicating the possibility of enhancing regenerative processes by combining cell and gene therapy strategies. It has been hypothesized that genetically modified cells exert both autocrine and paracrine effects, recruiting host cells to the site of implantation and resulting in enhanced osteogenesis [83]. Importantly, recruitment of host cells could allow for a reduced number of exogenous cells that need to be implanted. In many studies, adult stem cells have been engineered to express genes of the bone morphogenetic protein family (for example, $B M P 2, B M P 4$, and $B M P 7$ ). Other genes of interest include those encoding transcription factors essential for osteoblast differentiation (for example, core binding factor $\alpha 1$ (Cbfa1), and Osterix), factors enhancing angiogenesis (for example, vascular endothelial growth factor), and bone formation antagonists (for example, noggin) for an additional level of control over bone formation, and combinations of several factors [83]. The challenges lay in efficiently delivering therapeutic genes into the cells without adenoviral and retroviral vectors - for example, by nucleofection (a form of electropermeabilization) - in order to increase safety and allow for the subsequent development of clinical applications.

\section{Future prospects, clinical translation and regulation}

In addition to scientific challenges, several manufacturing, safety and regulatory issues need to be addressed before cell-based therapies can become routine clinical practice for the treatment of bone defects. Recently, the conditions allowing clinical scale production of cells for therapeutic purposes have been evaluated, including the possibility of automated culture $[84,85]$. Functional and structural criteria for bone grafts are not yet fully established, and might vary depending on the therapeutic purpose. In pre-clinical studies, load-bearing large animal models should generally be used to assess graft functionality, as research on small animals does not give relevant results due to major differences in graft size and healing properties.

Cell-based products are those requiring cell isolation, proliferation and differentiation, as well as application of supporting scaffolding materials. Under European Union regulations, cell-based products need to be manufactured in good manufacturing practice facilities under classic pharmaceutical standards [86,87]. The regulation of cellbased products falls under the categories of 'human cell, tissue, and cellular and tissue based products' $[88,89]$ in the USA, and 'advanced cell therapies' in Europe as defined in [86]. In addition, the International Society for Stem Cell Research published Guidelines for the Clinical Translation of Stem Cells [90], which highlight the scientific, clinical, regulatory, ethical, and social issues to be addressed for cell-based products and services. These documents address the safety and use of therapeutic cells, and regulate the necessary evaluations and permissions for the sourcing of material, especially for cells of allogeneic origin (patient information, genetic and infection screening, written informed consent for donors).

As a general principle, stem cell-based approaches should be clinically competitive or superior to existing therapies. The risks of using cell-based products should be carefully evaluated with respect to the benefits of enhanced functional outcome, application of one single procedure, reduction of cost, and improved quality of life. Clinical trials should be based on a clear rationale and justification of the procedure (with supporting preclinical data and comparisons to existing treatments), and should include characterization of the product, description of administration (including drugs and surgery) and plans for clinical follow-up and adverse events reporting.

\section{Conclusions}

Tissue-engineered bone constructs have the potential to alleviate the demand arising from the shortage of suitable autograft and allograft materials for augmenting bone healing. They also can serve as controllable in vitro models of high biological fidelity for studies of bone development, disease or regeneration. Each of the sources of osteogenic human cells - primary cells, MSCs, ESCs and induced pluripotent stem cells - has distinct advantages when used for bone tissue engineering, and the quest for an 'ideal' cell source is still in progress. 
Technologies are critical for unlocking the full biological potential of any cell type. To this end, advanced scaffolds (with molecular, structural and mechanical properties designed to mimic bone) and bioreactors (with environmental control and biophysical signaling for enhanced osteogenesis) are being developed to engineer bone grafts and to test the osteogenic capacity of stem cells. Because bone is a vascularized tissue that is actively remodeled through coordinated sequences of bone growth and resorbtion, the requirements are much more complex than 'just' the formation of mineralized bone matrix. The need for a vascular compartment, as well as for coordinated activity of osteoblasts and osteoclasts, pose major challenges to directed differentiation of stem cells. Ongoing research is advancing from the ability to engineer centimeter-size bone tissue constructs containing viable cells and mineralized matrix to engineering more complex tissue constructs that more closely resemble native bone. It remains to be seen how much can be done (and needs to be done) in vitro to obtain bone grafts for implantation, and to study disease and screen cells and therapeutic agents.

\section{Abbreviations}

ASC = adipose stem cell; BMSC = bone marrow mesenchymal stem cell; ESC = embryonic stem cell; MSC = mesenchymal stem cell.

\section{Competing interests}

The authors declare that they have no competing interests.

\section{Authors' contributions}

All authors contributed to the writing of the manuscript, as well as read and approved the final version.

\section{Acknowledgements}

We would like to thank Nebojsa Mirkovic for helping with the figures. This work was supported by the New York Stem Cell Foundation (Darja Marolt is a NYSCF - Stanley and Fiona Druckenmiller fellow), National Institutes of Health (DE16525-01 and EB002520 to Gordana Vunjak Novakovic), and the Ministry of Higher Education, Science and Technology Republic of Slovenia (ARRS-SLO L4-6325-0106-06, 3211-06-000539, P3-0371 to Miomir Knezevic).

\section{Author details}

'Department of Biomedical Engineering, Columbia University, 622 West 168th Street, New York, NY 10032, USA. ${ }^{2}$ Bloood Transfusion Centre of Slovenia,

Šlajmerjeva 6, Ljubljana 1000, Slovenia.

Published: 4 May 2010

\section{References}

1. Lee NK, Sowa H, Hinoi E, Ferron M, Ahn JD, Confavreux C, Dacquin R, Mee PJ, McKee MD, Jung DY, Zhang Z, Kim JK, Mauvais-Jarvis F, Ducy P, Karsenty G: Endocrine regulation of energy metabolism by the skeleton. Cell 2007, 130:456-469.

2. Baron R: Diseases of bone and mineral metabolism: Anatomy and ultrastructure of bone - histogenesis, growth and remodeling. 2008 [http://www.endotext.org/parathyroid/parathyroid1/parathyroidframe1.htm]

3. Kronenberg HM: Developmental regulation of the growth plate. Nature 2003, 423:332-336.

4. Tang Y, Wu X, Lei W, Pang L, Wan C, Shi Z, Zhao L, Nagy TR, Peng X, Hu J, Feng X, Van Hul W, Wan M, Cao X: TGF-beta1-induced migration of bone mesenchymal stem cells couples bone resorption with formation. Nat Med 2009, 15:757-765.

5. Einhorn TA: The cell and molecular biology of fracture healing. Clin Orthop Relat Res 1998:S7-21.
6. Khan SN, Cammisa FP Jr, Sandhu HS, Diwan AD, Girardi FP, Lane JM: The biology of bone grafting. J Am Acad Orthop Surg 2005, 13:77-86.

7. Frohlich M, Grayson WL, Wan LQ, Marolt D, Drobnic M, Vunjak-Novakovic G: Tissue engineered bone grafts: biological requirements, tissue culture and clinical relevance. Curr Stem Cell Res Ther 2008, 3:254-264.

8. Vunjak-Novakovic G, Meinel L, Altman G, Kaplan D: Bioreactor cultivation of osteochondral grafts. Orthod Craniofac Res 2005, 8:209-218.

9. Mygind T, Stiehler M, Baatrup A, Li H, Zou X, Flyvbjerg A, Kassem M, Bunger C: Mesenchymal stem cell ingrowth and differentiation on coralline hydroxyapatite scaffolds. Biomaterials 2007, 28:1036-1047.

10. Boukhechba F, Balaguer T, Michiels JF, Ackermann K, Quincey D, Bouler JM, Pyerin W, Carle GF, Rochet N: Human primary osteocyte differentiation in a 3D culture system. J Bone Miner Res 2009, 24:1927-1935.

11. Turhani D, Watzinger E, Weissenbock M, Yerit K, Cvikl B, Thurnher D, Ewers R: Three-dimensional composites manufactured with human mesenchymal cambial layer precursor cells as an alternative for sinus floor augmentation: an in vitro study. Clin Oral Implants Res 2005, 16:417-424

12. Meinel L, Karageorgiou V, Fajardo R, Snyder B, Shinde-Patil V, Zichner L, Kaplan D, Langer R, Vunjak-Novakovic G: Bone tissue engineering using human mesenchymal stem cells: effects of scaffold material and medium flow. Ann Biomed Eng 2004, 32:112-122.

13. Chesnutt BM, Yuan Y, Buddington $K$, Haggard WO, Bumgardner JD: Composite chitosan/nano-hydroxyapatite scaffolds induce osteocalcin production by osteoblasts in vitro and support bone formation in vivo. Tissue Eng Part A 2009, 15:2571-2579.

14. Hofmann S, Hagenmuller H, Koch AM, Muller R, Vunjak-Novakovic G, Kaplan $\mathrm{DL}$, Merkle HP, Meinel L: Control of in vitro tissue-engineered bone-like structures using human mesenchymal stem cells and porous silk scaffolds. Biomaterials 2007, 28:1152-1162.

15. Dalby MJ, Gadegaard N, Tare R, Andar A, Riehle MO, Herzyk P, Wilkinson CD, Oreffo RO: The control of human mesenchymal cell differentiation using nanoscale symmetry and disorder. Nat Mater 2007, 6:997-1003.

16. Comisar WA, Kazmers NH, Mooney DJ, Linderman JJ: Engineering RGD nanopatterned hydrogels to control preosteoblast behavior: a combined computational and experimental approach. Biomaterials 2007, 28:4409-4417.

17. Engler AJ, Sen S, Sweeney HL, Discher DE: Matrix elasticity directs stem cell lineage specification. Cell 2006, 126:677-689.

18. Karageorgiou V, Tomkins M, Fajardo R, Meinel L, Snyder B, Wade K, Chen J, Vunjak-Novakovic G, Kaplan DL: Porous silk fibroin 3-D scaffolds for delivery of bone morphogenetic protein-2 in vitro and in vivo. J Biomed Mater Res A 2006, 78:324-334.

19. Chao PH, Grayson W, Vunjak-Novakovic G: Engineering cartilage and bone using human mesenchymal stem cells. J Orthop Sci 2007, 12:398-404.

20. Grayson WL, Bhumiratana S, Cannizzaro C, Chao PH, Lennon DP, Caplan Al, Vunjak-Novakovic G: Effects of initial seeding density and fluid perfusion rate on formation of tissue-engineered bone. Tissue Eng Part A 2008, 14:1809-1820.

21. Frohlich M, Grayson W, Marolt D, Gimble J, Velikonja NK, Vunjak-Novakovic G: Bone grafts engineered from human adipose-derived stem cells in perfusion bioreactor culture. Tissue Eng Part A 2010, 16:179-189.

22. Sikavitsas VI, Bancroft GN, Holtorf HL, Jansen JA, Mikos AG: Mineralized matrix deposition by marrow stromal osteoblasts in 3D perfusion culture increases with increasing fluid shear forces. Proc Natl Acad Sci U S A 2003, 100:14683-14688.

23. Sittichockechaiwut A, Scutt AM, Ryan AJ, Bonewald LF, Reilly GC: Use of rapidly mineralising osteoblasts and short periods of mechanical loading to accelerate matrix maturation in 3D scaffolds. Bone 2009, 44:822-829.

24. Muschler GF, Nakamoto C, Griffith LG: Engineering principles of clinical cell-based tissue engineering. J Bone Joint Surg Am 2004, 86-A:1541-1558.

25. Mailhot JM, Borke JL: An isolation and in vitro culturing method for human intraoral bone cells derived from dental implant preparation sites. Clin Oral Implants Res 1998, 9:43-50.

26. Jonsson KB, Frost A, Nilsson O, Ljunghall S, Ljunggren O: Three isolation techniques for primary culture of human osteoblast-like cells: a comparison. Acta Orthop Scand 1999, 70:365-373.

27. Voegele TJ, Voegele-Kadletz M, Esposito V, Macfelda K, Oberndorfer U, Vecsei $\checkmark$, Schabus R: The effect of different isolation techniques on human osteoblast-like cell growth. Anticancer Res 2000, 20:3575-3581.

28. Hutmacher DW, Sittinger M: Periosteal cells in bone tissue engineering. Tissue Eng 2003, 9(Suppl 1):S45-64. 
29. Defino HL, da Silva Herrero CF, Crippa GE, Bellesini LS, Beloti MM, Rosa AL: In vitro proliferation and osteoblastic phenotype expression of cells derived from human vertebral lamina and iliac crest. Spine (Phila Pa 1976) 2009, 34:1549-1553

30. Montjovent MO, Burri N, Mark S, Federici E, Scaletta C, Zambelli PY, Hohlfeld P, Leyvraz PF, Applegate LL, Pioletti DP: Fetal bone cells for tissue engineering. Bone 2004, 35:1323-1333.

31. Tuli R, Tuli S, Nandi S, Wang ML, Alexander PG, Haleem-Smith H, Hozack WJ, Manner PA, Danielson KG, Tuan RS: Characterization of multipotential mesenchymal progenitor cells derived from human trabecular bone. Stem Cells 2003, 21:681-693.

32. De Bari C, Dell'Accio F, Vanlauwe J, Eyckmans J, Khan IM, Archer CW, Jones EA, McGonagle D, Mitsiadis TA, Pitzalis C, Luyten FP: Mesenchymal multipotency of adult human periosteal cells demonstrated by single-cell lineage analysis. Arthritis Rheum 2006, 54:1209-1221.

33. Marolt D, Cozin M, Vunjak-Novakovic G, Landesberg R: Effects of pamidronate on primary human osteoblast-like cells. Transactions ORS 2009, 34:0116.

34. Akintoye SO, Lam T, Shi S, Brahim J, Collins MT, Robey PG: Skeletal sitespecific characterization of orofacial and iliac crest human bone marrow stromal cells in same individuals. Bone 2006, 38:758-768.

35. Beresford JN, Gallagher JA, Poser JW, Russell RG: Production of osteocalcin by human bone cells in vitro. Effects of 1,25(OH)2D3, 24,25(OH)2D3, parathyroid hormone, and glucocorticoids. Metab Bone Dis Relat Res 1984, 5:229-234.

36. Siggelkow H, Rebenstorff K, Kurre W, Niedhart C, Engel I, Schulz H, Atkinson MJ, Hufner M: Development of the osteoblast phenotype in primary human osteoblasts in culture: comparison with rat calvarial cells in osteoblast differentiation. J Cell Biochem 1999, 75:22-35.

37. Jaquiery C, Schaeren S, Farhadi J, Mainil-Varlet P, Kunz C, Zeilhofer HF, Heberer $M$, Martin I: In vitro osteogenic differentiation and in vivo bone-forming capacity of human isogenic jaw periosteal cells and bone marrow stromal cells. Ann Surg 2005, 242:859-867, discussion 867-858.

38. Xiao Y, Qian H, Young WG, Bartold PM: Tissue engineering for bone regeneration using differentiated alveolar bone cells in collagen scaffolds. Tissue Eng 2003, 9:1167-1177

39. Alexander D, Hoffmann J, Munz A, Friedrich B, Geis-Gerstorfer J, Reinert S: Analysis of OPLA scaffolds for bone engineering constructs using human jaw periosteal cells. J Mater Sci Mater Med 2008, 19:965-974.

40. Giannoudis PV, Dinopoulos H, Tsiridis E: Bone substitutes: an update. Injury 2005, 36(Suppl 3):S20-27

41. Ahlmann E, Patzakis M, Roidis N, Shepherd L, Holtom P: Comparison of anterior and posterior iliac crest bone grafts in terms of harvest-site morbidity and functional outcomes. J Bone Joint Surg Am 2002, 84-A:716-720.

42. Li J, Wang HL: Common implant-related advanced bone grafting complications: classification, etiology, and management. Implant Dent 2008, 17:389-401.

43. Pittenger MF, Mackay AM, Beck SC, Jaiswal RK, Douglas R, Mosca JD, Moorman MA, Simonetti DW, Craig S, Marshak DR: Multilineage potential of adult human mesenchymal stem cells. Science 1999, 284:143-147.

44. Zuk PA, Zhu M, Mizuno H, Huang J, Futrell JW, Katz AJ, Benhaim P, Lorenz HP, Hedrick MH: Multilineage cells from human adipose tissue: implications for cell-based therapies. Tissue Eng 2001, 7:211-228.

45. Sudo K, Kanno M, Miharada K, Ogawa S, Hiroyama T, Saijo K, Nakamura Y: Mesenchymal progenitors able to differentiate into osteogenic, chondrogenic, and/or adipogenic cells in vitro are present in most primary fibroblast-like cell populations. Stem Cells 2007, 25:1610-1617.

46. Caplan Al: Adult mesenchymal stem cells for tissue engineering versus regenerative medicine. J Cell Physiol 2007, 213:341-347.

47. Friedenstein AJ, Chailakhyan RK, Gerasimov UV: Bone marrow osteogenic stem cells: in vitro cultivation and transplantation in diffusion chambers. Cell Tissue Kinet 1987, 20:263-272.

48. Finkemeier CG: Bone-grafting and bone-graft substitutes. J Bone Joint Surg Am 2002, 84-A:454-464.

49. Bianco P, Riminucci M, Gronthos S, Robey PG: Bone marrow stromal stem cells: nature, biology, and potential applications. Stem Cells 2001, 19:180-192.

50. Martin I, Muraglia A, Campanile G, Cancedda R, Quarto R: Fibroblast growth factor-2 supports ex vivo expansion and maintenance of osteogenic precursors from human bone marrow. Endocrinology 1997, 138:4456-4462.
51. Mauney JR, Kaplan DL, Volloch V: Matrix-mediated retention of osteogenic differentiation potential by human adult bone marrow stromal cells during ex vivo expansion. Biomaterials 2004, 25:3233-3243.

52. Gimble JM, Katz AJ, Bunnell BA: Adipose-derived stem cells for regenerative medicine. Circ Res 2007, 100:1249-1260.

53. Jurgens WJ, Oedayrajsingh-Varma MJ, Helder MN, Zandiehdoulabi B, Schouten TE, Kuik DJ, Ritt MJ, van Milligen FJ: Effect of tissue-harvesting site on yield of stem cells derived from adipose tissue: implications for cellbased therapies. Cell Tissue Res 2008, 332:415-426.

54. Hattori H, Sato M, Masuoka K, Ishihara M, Kikuchi T, Matsui T, Takase B, Ishizuka T, Kikuchi M, Fujikawa K: Osteogenic potential of human adipose tissuederived stromal cells as an alternative stem cell source. Cells Tissues Organs 2004, 178:2-12

55. Kim HJ, Kim UJ, Vunjak-Novakovic G, Min BH, Kaplan DL: Influence of macroporous protein scaffolds on bone tissue engineering from bone marrow stem cells. Biomaterials 2005, 26:4442-4452.

56. McCullen SD, Zhu Y, Bernacki SH, Narayan RJ, Pourdeyhimi B, Gorga RE, Loboa EG: Electrospun composite poly(L-lactic acid)/tricalcium phosphate scaffolds induce proliferation and osteogenic differentiation of human adipose-derived stem cells. Biomed Mater 2009, 4:35002.

57. Grayson WL, Frohlich M, Yeager K, Bhumiratana S, Chan ME, Cannizzaro C, Wan LQ, Liu XS, Guo XE, Vunjak-Novakovic G: Engineering anatomically shaped human bone grafts. Proc Natl Acad Sci U S A 2010, 107:3299-3304.

58. Scherberich A, Galli R, Jaquiery C, Farhadi J, Martin I: Three-dimensional perfusion culture of human adipose tissue-derived endothelial and osteoblastic progenitors generates osteogenic constructs with intrinsic vascularization capacity. Stem Cells 2007, 25:1823-1829.

59. Phinney DG, Kopen G, Righter W, Webster S, Tremain N, Prockop DJ: Donor variation in the growth properties and osteogenic potential of human marrow stromal cells. J Cell Biochem 1999, 75:424-436.

60. De Bari C, Dell'Accio F, Karystinou A, Guillot PV, Fisk NM, Jones EA, McGonagle D, Khan IM, Archer CW, Mitsiadis TA, Donaldson AN, Luyten FP, Pitzalis C: A biomarker-based mathematical model to predict bone-forming potency of human synovial and periosteal mesenchymal stem cells. Arthritis Rheum 2008, 58:240-250.

61. Røsland GV, Svendsen A, Torsvik A, Sobala E, McCormack E, Immervoll H, Mysliwietz J, Tonn JC, Goldbrunner R, Lønning PE, Bjerkvig R, Schichor C: Long-term cultures of bone marrow-derived human mesenchymal stem cells frequently undergo spontaneous malignant transformation. Cancer Res 2009, 69:5331-5339.

62. Izadpanah R, Kaushal D, Kriedt C, Tsien F, Patel B, Dufour J, Bunnell BA: Longterm in vitro expansion alters the biology of adult mesenchymal stem cells. Cancer Res 2008, 68:4229-4238.

63. Hoffman LM, Carpenter MK: Characterization and culture of human embryonic stem cells. Nat Biotechnol 2005, 23:699-708.

64. Thomson JA, Itskovitz-Eldor J, Shapiro SS, Waknitz MA, Swiergiel JJ, Marshall VS, Jones JM: Embryonic stem cell lines derived from human blastocysts. Science 1998, 282:1145-1147.

65. Ludwig TE, Levenstein ME, Jones JM, Berggren WT, Mitchen ER, Frane JL, Crandall LJ, Daigh CA, Conard KR, Piekarczyk MS, Llanas RA, Thomson JA: Derivation of human embryonic stem cells in defined conditions. Nat Biotechnol 2006, 24:185-187

66. Richards M, Tan S, Fong CY, Biswas A, Chan WK, Bongso A: Comparative evaluation of various human feeders for prolonged undifferentiated growth of human embryonic stem cells. Stem Cells 2003, 21:546-556.

67. International Stem Cell Initiative, Adewumi O, Aflatoonian B, Ahrlund-Richter L, Amit M, Andrews PW, Beighton G, Bello PA, Benvenisty N, Berry LS, Bevan S, Blum B, Brooking J, Chen KG, Choo AB, Churchill GA, Corbel M, Damjanov I, Draper JS, Dvorak P, Emanuelsson K, Fleck RA, Ford A, Gertow K, Gertsenstein M, Gokhale PJ, Hamilton RS, Hampl A, Healy LE, Hovatta O, et al.: Characterization of human embryonic stem cell lines by the International Stem Cell Initiative. Nat Biotechnol 2007, 25:803-816.

68. Jaenisch R, Young R: Stem cells, the molecular circuitry of pluripotency and nuclear reprogramming. Cell 2008, 132:567-582.

69. Draper JS, Smith K, Gokhale P, Moore HD, Maltby E, Johnson J, Meisner L, Zwaka TP, Thomson JA, Andrews PW: Recurrent gain of chromosomes 17q and 12 in cultured human embryonic stem cells. Nat Biotechnol 2004, 22:53-54.

70. Maitra A, Arking DE, Shivapurkar N, Ikeda M, Stastny V, Kassauei K, Sui G, Cutler DJ, Liu Y, Brimble SN, Noaksson K, Hyllner J, Schulz TC, Zeng X, Freed WJ, Crook J, Abraham S, Colman A, Sartipy P, Matsui S, Carpenter M, Gazdar 
AF, Rao M, Chakravarti A: Genomic alterations in cultured human embryonic stem cells. Nat Genet 2005, 37:1099-1103.

71. Takahashi K, Tanabe K, Ohnuki M, Narita M, Ichisaka T, Tomoda K, Yamanaka S: Induction of pluripotent stem cells from adult human fibroblasts by defined factors. Cell 2007, 131:861-872.

72. Zhou H, Wu S, Joo JY, Zhu S, Han DW, Lin T, Trauger S, Bien G, Yao S, Zhu Y, Siuzdak G, Schöler HR, Duan L, Ding S: Generation of induced pluripotent stem cells using recombinant proteins. Cell Stem Cell 2009, 4:381-384.

73. Bielby RC, Boccaccini AR, Polak JM, Buttery LD: In vitro differentiation and in vivo mineralization of osteogenic cells derived from human embryonic stem cells. Tissue Eng 2004, 10:1518-1525.

74. Tian XF, Heng BC, Ge Z, Lu K, Rufaihah AJ, Fan VT, Yeo JF, Cao T: Comparison of osteogenesis of human embryonic stem cells within 2D and 3D culture systems. Scand J Clin Lab Invest 2008, 68:58-67.

75. Ahn SE, Kim S, Park KH, Moon SH, Lee HJ, Kim GJ, Lee YJ, Cha KY, Chung HM: Primary bone-derived cells induce osteogenic differentiation without exogenous factors in human embryonic stem cells. Biochem Biophys Res Commun 2006, 340:403-408.

76. Inanc B, Elcin AE, Elcin YM: Effect of osteogenic induction on the in vitro differentiation of human embryonic stem cells cocultured with periodontal ligament fibroblasts. Artif Organs 2007, 31:792-800.

77. Karp JM, Ferreira LS, Khademhosseini A, Kwon AH, Yeh J, Langer RS: Cultivation of human embryonic stem cells without the embryoid body step enhances osteogenesis in vitro. Stem Cells 2006, 24:835-843.

78. Olivier EN, Rybicki AC, Bouhassira EE: Differentiation of human embryonic stem cells into bipotent mesenchymal stem cells. Stem Cells 2006, 24:1914-1922.

79. Barberi T, Willis LM, Socci ND, Studer L: Derivation of multipotent mesenchymal precursors from human embryonic stem cells. PLoS Med 2005, 2:e161.

80. Mateizel I, De Becker A, Van de Velde H, De Rycke M, Van Steirteghem A Cornelissen R, Van der Elst J, Liebaers I, Van Riet I, Sermon K: Efficient differentiation of human embryonic stem cells into a homogeneous population of osteoprogenitor-like cells. Reprod Biomed Online 2008, 16:741-753.

81. Boyd NL, Robbins KR, Dhara SK, West FD, Stice SL: Human embryonic stem cell-derived mesoderm-like epithelium transitions to mesenchymal progenitor cells. Tissue Eng Part A 2009, 15:1897-1907.

82. Kim S, Kim SS, Lee SH, Eun Ahn S, Gwak SJ, Song JH, Kim BS, Chung HM: In vivo bone formation from human embryonic stem cell-derived osteogenic cells in poly(d,l-lactic-co-glycolic acid)/hydroxyapatite composite scaffolds. Biomaterials 2008, 29:1043-1053.

83. Kimelman N, Pelled G, Helm GA, Huard J, Schwarz EM, Gazit D: Review: geneand stem cell-based therapeutics for bone regeneration and repair. Tissue Eng 2007, 13:1135-1150.

84. Dennis JE, Esterly K, Awadallah A, Parrish CR, Poynter GM, Goltry KL: Clinicalscale expansion of a mixed population of bone-marrow-derived stem and progenitor cells for potential use in bone-tissue regeneration. Stem Cells 2007, 25:2575-2582

85. Sotiropoulou PA, Perez SA, Salagianni M, Baxevanis CN, Papamichail M: Characterization of the optimal culture conditions for clinical scale production of human mesenchymal stem cells. Stem Cells 2006, 24:462-471.
86. Regulation (EC) No 1394/2007 of the European Parliament and of the Council of 13 November 2007, on advanced therapy medicinal products and amending Directive 2001/83/EC and Regulation (EC) No726/2004. European Comission, 2007 [http://eur-lex.europa.eu/LexUriServ/LexUriServ.d o?uri=OJ:L:2007:324:0121:0137:en:PDF]

87. Slaper-Cortenbach I, Scott M, Herrmann D, Introna M, Theunissen K, Theocharous P, Chabannon C: Cell Therapy cGMP Facilities and Manufacturing: the Regulatory Situation for Academic Cell Therapy Facilities in Europe. New York: Springer; 2009

88. FDA: Code of Federal Regulations Title 21, Part 1271 - Human cells, tissue, and cellular and tissue-based products [http://www.accessdata.fda.gov/ scripts/cdrh/cfdocs/cfcfr/CFRSearch.cfm?CFRPart=1271]

89. Lindblad RW: Cell Therapy CGMP Facilities and Manufacturing: Regulation of Cell Product Manufacturing and Delivery: a United States perspective. New York: Springer; 2009.

90. ISSCR: Guidelines for the Clinical Translation of Stem Cells. 2008 [http:// www.isscr.org/clinical_trans/pdfs/ISSCRGLClinicalTrans.pdf]

91. Quarto R, Mastrogiacomo M, Cancedda R, Kutepov SM, Mukhachev V, Lavroukov A, Kon E, Marcacci M: Repair of large bone defects with the use of autologous bone marrow stromal cells. N Engl J Med 2001, 344:385-386.

92. Lendeckel S, Jodicke A, Christophis P, Heidinger K, Wolff J, Fraser JK, Hedrick $\mathrm{MH}$, Berthold L, Howaldt HP: Autologous stem cells (adipose) and fibrin glue used to treat widespread traumatic calvarial defects: case report. J Craniomaxillofac Surg 2004, 32:370-373.

93. Schmelzeisen R, Schimming R, Sittinger M: Making bone: implant insertion into tissue-engineered bone for maxillary sinus floor augmentation a preliminary report. J Craniomaxillofac Surg 2003, 31:34-39.

94. Schimming R, Schmelzeisen R: Tissue-engineered bone for maxillary sinus augmentation. J Oral Maxillofac Surg 2004, 62:724-729.

95. Strietzel FP: Tissue-engineered bone for lateral alveolar ridge augmentation: a case report. Int J Oral Maxillofac Implants 2006, 21:131-135.

96. Springer IN, Nocini PF, Schlegel KA, De Santis D, Park J, Warnke PH, Terheyden H, Zimmermann R, Chiarini L, Gardner K, Ferrari F, Wiltfang J: Two techniques for the preparation of cell-scaffold constructs suitable for sinus augmentation: steps into clinical application. Tissue Eng 2006, 12:2649-2656.

97. Zizelmann C, Schoen R, Metzger MC, Schmelzeisen R, Schramm A, Dott B, Bormann $\mathrm{KH}$, Gellrich NC: Bone formation after sinus augmentation with engineered bone. Clin Oral Implants Res 2007, 18:69-73.

98. Beaumont C, Schmidt RJ, Tatakis DN, Zafiropoulos GG: Use of engineered bone for sinus augmentation. J Periodontol 2008, 79:541-548.

99. Shayesteh YS, Khojasteh A, Soleimani M, Alikhasi M, Khoshzaban A, Ahmadbeigi N: Sinus augmentation using human mesenchymal stem cells loaded into a beta-tricalcium phosphate/hydroxyapatite scaffold. Oral Surg Oral Med Oral Pathol Oral Radiol Endod 2008, 106:203-209.

100. Putzier M, Strube P, Funk J, Gross C, Perka C: Periosteal cells compared with autologous cancellous bone in lumbar segmental fusion. J Neurosurg Spine 2008, 8:536-543.

doi:10.1186/scrt10

Cite this article as: Marolt D, et al:: Bone tissue engineering with human stem cells. Stem Cell Research \& Therapy 2010, 1:10. 